\title{
Minicircle DNA-Mediated CAR T Cells Targeting CD44 Suppressed Hepatocellular Carcinoma Both in vitro and in vivo [Corrigendum]
}

\author{
Wang $\mathrm{H}$, Ye X, Ju Y, et al. Onco Targets Ther. \\ 2020;13:3703-3716.
}

The authors have advised the correspondence address on page 3703 is incorrect. The correct correspondence address is as follows.

Correspondence: Jianhui Cai

Department of Surgery, Hebei Medical University, 361 East Zhongshan Road, Shijiazhuang, Hebei 050017, People's Republic of China
OncoTargets and Therapy

\section{Publish your work in this journal}

OncoTargets and Therapy is an international, peer-reviewed, open access journal focusing on the pathological basis of all cancers, potential targets for therapy and treatment protocols employed to improve the management of cancer patients. The journal also focuses on the impact of management programs and new therapeutic

\author{
Tel +8613315124890 \\ Fax +86031186266193 \\ Email jianhuicai201@163.com
}

The authors apologize for this error. 